\title{
Analyzing changes in a leach solution oxygenation in the process of uranium ore borehole mining
}

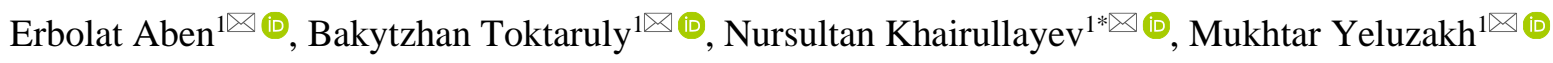

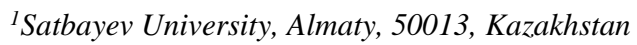 \\ *Corresponding author: e-mail khayrullaev.n@gmail.com, tel.+7751833333
}

\begin{abstract}
Purpose is to increase uranium content in a PR solution while developing a technique varying oxidation-reduction potential of a leach solution with its oxygenation and identify changes in the oxygenation depending upon sulfuric acid concentration as well as transportation distance of the solution.

Methods. A laboratory facility, involving solution tank, pump, Venturi tube, tank to install oxygen analyzer, and a dump tank, has been manufactured under the lab conditions to determine a leach solution oxygenation taking into consideration its delivery rate, sulfuric acid concentration, and temporal preservation of the concentration. Solution flow velocity; the delivered solution volume; sulfuric acid concentration; and distance from oxygenation point to a seam changed and varied during the study. Oxygenation was measured with the help of AZ 8403 oximeter; IT-1101 device was used to measure pH value as well as oxidation-reduction potential (ORP).

Findings. A technique for a leach solution oxygenation and results of laboratory tests to identify influence of a sulfuric acid as well as transportation distance of a solution on oxygen concentration in the solution have been represented. It has been determined that Venturi tube helps oxygenize a leach solution; in this context, maximum oxygen concentration is achieved if a flow velocity is optimum one. It has been specified that a solution oxygenating depends upon a sulfuric acid concentration decreasing moderately with the increasing distance of the solution transportation.
\end{abstract}

Originality. Following new dependencies have been determined: oxygen concentration in a solution upon a flow velocity and solution volume; and oxygen concentration in a solution upon distance from concentration place and sulfuric acid concentration.

Practical implications. A leach solution oxygenation results in the increased oxidation-reduction potential and in the increased content of a useful component in the pregnant solution respectively. The proposed technique is notable for its low capital spending. Moreover, it is integrated easily into the available system being absolutely environmentally friendly.

Keywords: saturation, oxygen, borehole, sulfuric acid, leach solution, pregnant solution, flow velocity

\section{Introduction}

Recently, nuclear energetics, ranking No. 4 in the world power balance after coal-fired power industry (40\%), gas industry (21\%), and hydraulic power industry (more than $16 \%$ ), has become the most important factor influencing the situation of the global uranium market and its development tendencies [1]. Taking into consideration the global population growth and large-scale industry development, increase in energy demand becomes more rapid relative to earlier forecasts. In this context, experts expect that new energy sources will not be involved industrially and at competitive prices before 2030 . Lack of fossil power resources becomes more and more acute problem. In the near future, relatively cheap and available reserves of crude oil, gas, and coal will be mined, extracted, and produced from the Earth's interior [2]-[5]. It goes without saying that issue of extraction of rare earth elements from technogenic deposits will be faced [6], [7].

Accelerating progress of nuclear energetics, becoming more and more essential component of energy generation, is a feature of scientific and technological revolution [8]-[10]. Such a giant development scale of nuclear energetics needs its provision by natural uranium. Hence, demand for uranium will increase. The demand can be satisfied at the expense of the traditional industrial ore extraction (i.e. in-situ mining and open pit mining), involvement of mainly hydrogenous genesis deposits, represented by base or lean ore, as well as deposits occurring under the complicated mining and hydrogeological conditions [11], [12]. Until recently, deposits of group two with uraniferous base or lean ore, were not developed using traditional methods on the technical and economic considerations [13], [14]. The crucial economic problem 
has been largely resolved. Recent decade has been marked by the major efforts to develop and implement industrially geotechnological uranium mining called as a method of in-situ borehole leaching [15]-[18].

Prime cost of mining with the use of in-situ borehole leaching (ISBL) through wells is 2.5 to 3 times lower than in-situ mining. Hence, the method remains the most promising one. In terms of ISBL, uranium behaviour depends heavily upon mineral composition of the deposit as well as upon its type and age. For instance, black compounds and oxidized minerals resolve best; nasturan, uraninite, and pitchblende resolve worse. Furthermore, $\mathrm{U}^{4+}$ minerals (i.e. uraninite, nasturan, and coffinite) resolve efficiently if only oxidizers, favouring increase of oxidation-reduction potential in the seam, are available [19], [20].

Analysis of scientific sources has helped conclude that the uranium leaching by means of sulfurous solutions depends heavily upon ORP of leach solutions which value is identified with the help of $\mathrm{Fe}$ (III)-Fe(II) concentration ratio. It is common knowledge that ferric ions are applied for a sulfurous solution to leach uranium ore. The increased share of ferric ions favours intensification of oxidation-reduction potential in turn enhancing a process of in-situ borehole leaching and reducing a unit rate of sulfur for leaching and overacidification. Consequently, selection of optimum ORP as well as optimum oxidizer to force it up may be quite important measure [15], [21].

Oxidation-reduction reactions, taking place in a seam, generally define efficiency of a leaching technique; a rate of metal recovery into a solution; specific consumption of chemicals; power consumption; as well as technical and economic performance, and environmental production factors on the whole.

Nevertheless, tetravalent uranium is slightly soluble both in acidic medium and alkaline medium. To achieve economically acceptable uranium leaching from ore, it is quite important to oxidize it up to hexavalent state being of higher solvability [21]-[24][23]. As a rule, trivalent iron compounds are applied for the purpose. Such factors as $\mathrm{pH}$, redox conditions, and solvent concentrations in a leaching solution influences uranium leaching from an ore layer [21].

Authors of paper [22] used ferric salt as an oxidizer. Experiments, carried out in a sulfuric leaching regime with addition of ferric iron, show $30-35 \%$ decrease in sulfuric acid consumption. When $\mathrm{Fe}$ (III) content increased up to $2 \mathrm{~g} / \mathrm{l}$, intensity of uranium transition into a solution achieved its maximum; leaching period reduced drastically; and L:S value for a design recovery factor decreased. However, it has been identify that if L:S ratio exceeds1.5-2.0 then availability of $\mathrm{Fe}(\mathrm{III})$ within the standard solutions cannot influence a rate of uranium transition into the solution.

Oxidization of a leaching solution is one of ways to increase oxidation degree. Practices of in-situ borehole leaching support the idea that uranium mining efficiency is interconnected with mass of atmospheric oxygen dissolved in the delivered (standard) solutions. In turn, amount of the dissolved air is determined by means of hydraulic pressure values formed when injection and drainage (discharge, pumping) production wells are interacting [25]-[27].

The method history considered a process of the compressed air injection into a seam as well as early oxygenation of standard solutions [22]. For instance, air was pumping under $2-4 \mathrm{~kg} / \mathrm{cm}^{2}$ pressure into experimental block 3 of insitu leaching site 10 of Uchkuduk deposit until $0.1 \mathrm{~kg} / \mathrm{t}$ oxy- genation of productive formation which corresponded to pore volume value [23]. After 30 days of operation of production wells, uranium content in pregnant solutions achieved its maximum (i.e. $35 \mathrm{mg} / \mathrm{l}$ ); in this context, $\mathrm{HCO}_{3}$ content was $270 \mathrm{mg} / \mathrm{l}$. By comparison, uranium content in pregnant solution achieved maximally $10 \mathrm{mg} / \mathrm{l}$ within blocks of sulfuric leaching regime. In this context, air was supplied through injection wells. The air was ejected with the help of a perforated pipe run to a bottom hole. The experiments have helped understand that minimum degree of air saturation, influencing intensity of uranium transition to a solution, starts from $0.1 \mathrm{~kg} / \mathrm{t}$ of ore mass. Moreover, oxygenation of a leaching solution in the field is a very difficult technological operation.

Mainly, three operation schedules of air supply were tested:

- compressed air delivery and expulsion of formation water of a productive level beyond the experimental site;

- build up pressure of the supply air to increase saturation degree of the standard solutions;

- air delivery through purposely designed dispersant preventing from formation of the dispersed insoluble air bubbles within underground water resulting in colmation of steam space of the ore seam.

It is well known that different factors, inclusive of temperature, pressure and others, influence solution oxygenation. For instance, 0 up to $70^{\circ} \mathrm{C}$ temperature rise of a solution factors into $14.6 \mathrm{mg} / \mathrm{l}$ down to $2.9 \mathrm{mg} / \mathrm{l}$ decrease in a solution oxygenation. However, under the conditions of in-situ well leaching, drop of a solution temperature ends in the decreased uranium extraction.

In addition, changes in 90,60 , and $30 \mathrm{~m}$ water pressures factors into 12,25 , and $100 \mathrm{mg} / \mathrm{l}$ of water dissolved in process media. In terms of $\mathrm{pH}=3.4$, uranium concentrations within the solutions achieved 7, 20, and $50 \mathrm{mg} / \mathrm{l}$ respectively.

Analysis of different techniques intensifying leaching has shown that they accelerate the process and increase several times useful mineral extraction [28], [29]. Nevertheless, they are not versatile and depend upon conditions of specific deposits. The abovementioned methods involve certain material inputs. Moreover, there is no available research identifying influence of sulfuric acid in a solution and oxygen saturation maintaining in the long term. Solution oxygenation using Venturi tube is proposed to avoid the disadvantages; increase uranium extraction; and reduce the time for a deposit mining [30], [31].

Hence, the research purpose is to increase uranium content in a pregnant solution while developing a technique varying oxidation-reduction potential of a leach solution with its oxygenation and identifying changes in the oxygenation depending upon sulfuric acid concentration as well as transportation distance of the solution.

Hence, the research problems are to:

- develop a technique to oxygenate a solution;

- carry out laboratory tests to determine effect of a flow velocity and the delivered solution on the oxygenation degree;

- identify dependencies of oxygen concentration upon distance of saturation point as well as upon sulfuric acid concentration.

\section{Methods}

Idea of the technique, using Venturi pipe to oxygenate a solution, is as follows (Fig. 1). Venturi pipe is a short pipe of a special structure with a diameter narrowing or reducing in its central part, and air inlet. 


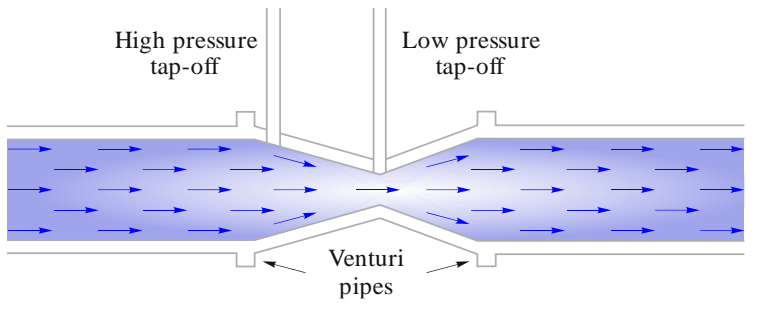

Figure 1. Venturi pipe

When a solution is passing through the narrowing, flow acceleration takes place with simultaneous air inflow. According to Bernoulli's principle, volume of fluid of leach solution, passing through a pipe with a larger diameter, will pass through a narrow part per unit time as well. However, proceeding from Bernoulli's principle, conditional provision of similar fluid amount in two points will accelerate the fluid rate in a narrow share of the pipe. The higher the fluid rate is, the lower static pressure is.

Fluid rate-static pressure ratio is in direct proportion, i.e. while accelerating fluid flow and reducing a pipe diameter, one may decrease pressure down to a value, in terms of which air inflow is provided within the narrowed pipe share. In such a case, active air-solution intermixing takes place favouring efficient oxygen transition from air to the solution. As Figure 1 demonstrates, initially either fluid or leaching solution passes through large pipe diameter. Then, within a narrowing area, the fluid passes from a laminar flow to a turbulent one where chaotic, extremely spasmodic motion of the fluid takes place. The motion is followed by active lateral mixing as well as velocity and pressure pulsations. In turn, the abovementioned results in gas fragmentation right within the moving fluid. After that, the gas saturated solution returns to the larger diameter area. Within the space, the flow decelerates and the solution comes back to a laminar flow state. In this context, static pressure increases proportionally. Practices show that pressure influences heavily gas solubility in water. Air oxygen solubility increases along with pressure build up. Pressure influences slightly solubility of liquids and solids. While stating the data, one may confirm that the method makes it possible to oxidize cost effectively a standard solution, and avoid potential gas colmation.

To identify oxygenation of a leach solution taking into consideration its delivery rate, sulfur acid concentration, and saturation preservation with time, laboratory environment was used to manufacture a lab device consisting of a tank for solution, pump, Venturi pipe, container to install oxygen analyzer, and discharge vessel.

Plastic 501 tank is connected to a $60 \mathrm{~cm}$ flexible hose. To provide the required fluid flow velocity, horizontal pump is installed. At high speed, provided by the pump, the liquid passes through Venturi pipe. The solution, saturated by air oxygen, is discharged into a vessel to identify concentrations of the oxygen, dissolved in liquid. The vessel to measure oxygen in liquid consists of a hermetic cover on one side, and electrode on the opposite side. The tank is designed in such a way that a bored hole is within the hermetic cover to fill the collector with air-water mixture; an electrode, measuring the dissolved oxygen, is at the bottom.

During the tests, solution velocity was changed to $1.8 \mathrm{~m} / \mathrm{sec}$; volume of the delivered solution increased from 60 up to $110 \mathrm{l} / \mathrm{h}$; sulfuric acid concentration was changed from 1.0 up to $23.0 \mathrm{~g} / \mathrm{l}$; and distance from saturation place to a seam saturation varied from $0 \mathrm{~m}$ down to $80 \mathrm{~m}$ (being 800 meters to scale). Oxygen saturation was measure using AZ 8403 oxymeter; IT-1101 device was applied to identify $\mathrm{pH}$ and ORP values. First, it was required to determine influence of the flow velocity and volume of the delivered solution on the oxygenation degree. After maximum saturation was defined, the research was carried out to identify effect of sulfuric acid concentration and the solution transportation distance on the changes taking place in the solution oxygenation.

\section{Results and discussion}

Five laboratory tests were done to identify influence of flow velocity and volume of the delivered solution on the oxygenation procedure. Table 1 demonstrates results of the tests determining influence of a flow velocity and volume of the delivered solution on the oxygenation degree.

Table 1. Influence of a flow velocity and volume of the delivered solution on the oxygenation degree

\begin{tabular}{ccc}
\hline $\begin{array}{c}\text { Flow velocity } \\
(V), \mathrm{m} / \mathrm{sec}\end{array}$ & $\begin{array}{c}\text { Solution volume } \\
(Q p), \mathrm{l} / \mathrm{h}\end{array}$ & $\begin{array}{c}\text { Oxygen concentration } \\
(q), \mathrm{mg} / \mathrm{l}\end{array}$ \\
\hline & & 4.03 \\
\hline 0.30 & 60.0 & 6.30 \\
\hline 0.65 & 110.0 & 7.80 \\
\hline 1.00 & 97.0 & 8.20 \\
\hline 1.80 & 97.0 & 8.50 \\
\hline
\end{tabular}

As Table 1 explains, oxygen concentration in the initial solution is $4.03 \mathrm{mg} / \mathrm{l}$; when velocity of a solution flow is $0.3 \mathrm{~m} / \mathrm{sec}$, oxygen concentration achieves $6.3 \mathrm{mg} / \mathrm{l}$. Further acceleration of the solution flow (i.e. from 0.3 up to $1.8 \mathrm{~m} / \mathrm{sec}$ ) results in the increased oxygen concentration from 6.5 up to $8.5 \mathrm{mg} / \mathrm{l}$. Hence, degree of the solution oxygenation is more than double to compare with initial solution. It should be mentioned that a flow acceleration up to $0.7 \mathrm{~m} / \mathrm{sec}$ initiates sharp increase of oxygen concentration in a solution; further flow acceleration up to $1.8 \mathrm{~m} / \mathrm{sec}$ demonstrates minor changes in oxygen concentration. In this context, maximum oxygen concentration in a solution is achieved when $97 \mathrm{l} / \mathrm{h}$ solution volume is passing through a pipeline. By contrast, continued increase in the solution volume up to $110 \mathrm{l} / \mathrm{h}$ forces $7.8 \mathrm{l} / \mathrm{h}$ decrease in oxygen concentration. Hence, one can conclude that changes in a pipeline diameter bring about maximum velocity of a solution flow as well as such solution volume providing maximum oxygenation of a leaching solution.

The experiments have shown that Venturi pipe use to oxygenate solution is quite efficient procedure. Moreover, it is less labour-intensive process since traditionally aeration (i.e. oxygenation) is performed involving such expensive facilities as compressor; oxygenator, using pure oxygen; hydrogen peroxide etc. Idea of a compressor is a forcible air injection into a liquid with the help of submerged pipes. However, maximum air oxygenation in a solution will be comparable with the proposed technique. In addition, compressor cannot be efficient if it is required to oxygenate large liquid volume. Oxygenator with pure oxygen may achieve high water oxygenation achieving $50 \mathrm{mg} / \mathrm{l}$. Nevertheless, industrial operation of oxygenator is very complex and expensive process. From the viewpoint of oxygenation, use of hydrogen peroxide in a leaching solution demonstrates good results; although, the chemical solution is cost-intensive to be applied industrially.

Figure 2 shows dependencies of oxygen concentration in a solution upon the velocity of solution flow and solution volume. The dependencies result from processing of data of laboratory experiments. 


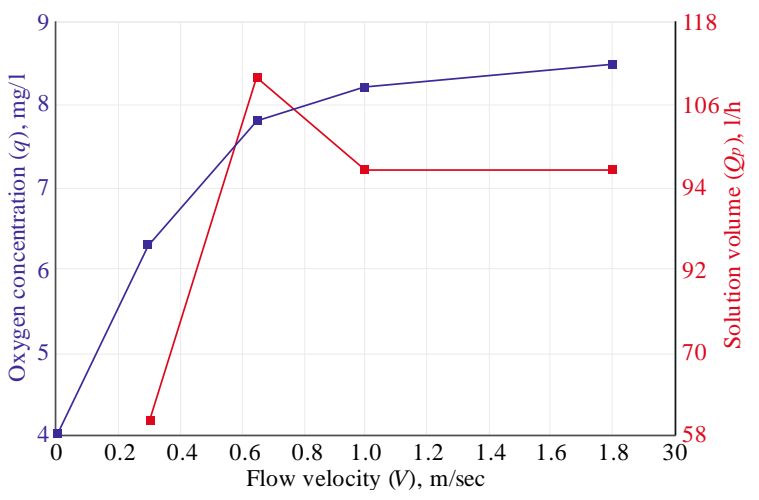

Figure 2. Dependencies of oxygen concentration in a solution upon solution flow and solution volume

After optimum velocity of a solution flow was determined, further experiments were carried out at such a flow rate which provided maximum oxygenation, i.e. $0.7 \mathrm{~m} / \mathrm{sec}$. In this context, sulfur acid concentration varied from 1.0 up to $23.0 \mathrm{~g} / \mathrm{l}$. Distance from oxygenation place also changed to $80 \mathrm{~m}$. Totally, five laboratory tests were carried out.

Table 2 demonstrates results of the laboratory experiments concerning determination of dependencies of a solution oxygenation upon sulfuric acid concentration as well as changes in oxygen concentration upon distance.

Table 2. Changes in oxygen concentration depending upon sulfuric acid concentration

\begin{tabular}{cccc}
\hline No. & $\begin{array}{c}\text { Distance from } \\
\text { saturation place } \\
\text { to a seam, } \mathrm{m}\end{array}$ & $\begin{array}{c}\text { Sulfuric acid } \\
\text { concentration, } \\
\mathrm{g} / \mathrm{l}\end{array}$ & $\begin{array}{c}\text { Oxygen } \\
\text { concentration in } \\
\text { a solution, } \mathrm{mg} / \mathrm{l}\end{array}$ \\
\hline 1 & 0 & 1.0 & 9.28 \\
\hline 2 & 0 & 13.0 & 9.45 \\
\hline 3 & 0 & 23.0 & 9.39 \\
\hline 4 & 20 & 1.0 & 9.11 \\
\hline 5 & 20 & 13.0 & 9.30 \\
\hline 6 & 20 & 23.0 & 9.52 \\
\hline 7 & 40 & 1.0 & 9.05 \\
\hline 8 & 40 & 13.0 & 9.26 \\
\hline 9 & 40 & 23.0 & 9.30 \\
\hline 10 & 80 & 1.0 & 8.98 \\
\hline 11 & 80 & 13.0 & 9.20 \\
\hline 12 & 80 & 23.0 & 9.24 \\
\hline
\end{tabular}

As the Table explains, if a leaching solution is oxygenated and sulfuric acid concentration varies from 1.0 to $23.0 \mathrm{~g} / \mathrm{l}$ within the oxygenating place then oxygen concentration increases from 9.28 to $9.39 \mathrm{mg} / \mathrm{l}$. Up to $40 \mathrm{~m}$ distancing from the oxygenation place as well as 1.0 to $23.0 \mathrm{~g} / \mathrm{l}$ changing in sulfuric acid concentration results in the $9.05-9.30 \mathrm{mg} / \mathrm{l}$ increase of oxygen concentration in the solution. Further distancing from oxygenation place (i.e. up to $80 \mathrm{~m}$ ) as well as changing in sulfuric acid concentration from 1.0 to $23.0 \mathrm{~g} / \mathrm{l}$ initiates minor oxygen concentration change, i.e. from 8.98 up to $9.24 \mathrm{mg} / \mathrm{l}$.

Figure 3 shows dependencies of oxygen concentration upon oxygenation place and sulfuric acid concentration resulting from processing of data represented in Table 2.

As Table 3 explains, increase of the sulfuric acid concentration in a solution is followed by increase in the solution oxygenation. For instance, 1.0 to $23.0 \mathrm{~g} / \mathrm{l}$ strengthening of a sulfuric acid and $20 \mathrm{~m}$ distancing from oxygenation place result in the increased saturation degree (i.e. from 9.11 to $9.52 \mathrm{mg} / \mathrm{l})$. Similar increase takes place in terms of varying distances from a place of a solution oxygenation.

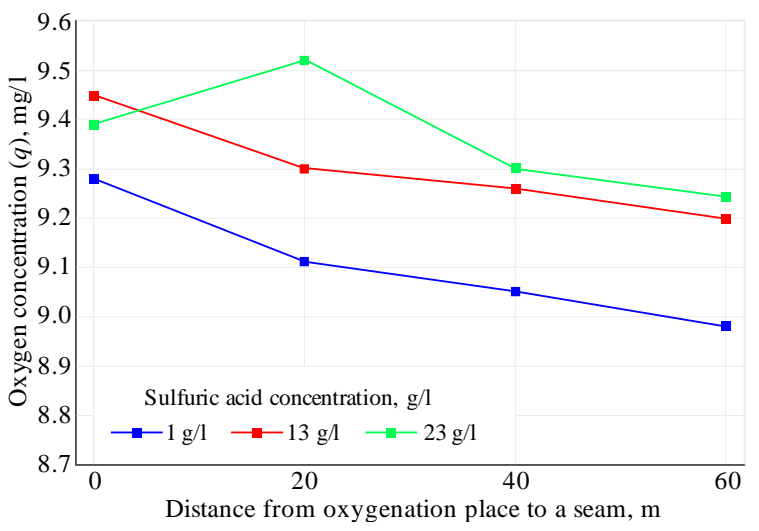

Figure 3. Dependencies of oxygen concentration upon the distance from oxygenation place and upon the sulfuric acid concentration

General tendency of oxygen concentration in a solution is observed depending upon increase in a distance from saturation place. For instance, if oxygen concentration is $9.45 \mathrm{mg} / \mathrm{l}$ within saturation place and concentration of a sulfur acid is $13 \mathrm{~g} / \mathrm{l}$ then it becomes $9.20 \mathrm{mg} / \mathrm{l}$ at $80 \mathrm{~m}$ distance, i.e. it decreases by $2.6 \%$.

Table 3. Changes in a solution oxygenation and ORP value depending upon time

\begin{tabular}{cccc}
\hline No. & $\begin{array}{c}\text { Sampling period, } \\
\text { minutes }\end{array}$ & $\begin{array}{c}\text { Solution } \\
\text { oxygenation, mg/l }\end{array}$ & ORP, mV \\
\hline 1 & Before saturation & 6.30 & 332 \\
\hline 2 & After saturation & 10.45 & \\
\hline 3 & 6 & 10.00 & 334 \\
\hline 4 & 9 & 9.98 & \\
\hline 5 & 11 & 9.96 & 337 \\
\hline 6 & 15 & 9.93 & 339 \\
\hline 7 & 25 & 9.86 & \\
\hline 8 & 30 & 9.77 & 343 \\
\hline 9 & 40 & 9.68 & \\
\hline 10 & 50 & 9.54 & 340 \\
\hline 11 & 65 & 9.50 & \\
\hline 12 & After saturation 67 & 10.36 & \\
\hline 13 & 99 & 9.92 & \\
\hline 15 & 128 & 9.38 & \\
\hline 16 & After saturation 131 & 10.03 & \\
\hline 17 & 161 & 8.28 & 7.23 \\
\hline 18 & 191 & 7.36 & \\
\hline 19 & 221 & 7.20 & \\
\hline & 251 & & \\
\hline
\end{tabular}

After the optimum flow velocity determination, the research was carried out in terms of such its velocity providing maximum oxygenation, i.e. $0.7 \mathrm{~m} / \mathrm{sec}$. In the process of the laboratory experiments to identify a solution oxygenation as well as its influence on ORP value, sampling period was 251 minutes at appropriate intervals. In this context, sulfur acid concentration was $10 \mathrm{~g} / \mathrm{l}$. Table 3 demonstrates results of the laboratory tests defining a period of solution oxygenation as well as changes in ORP value depending upon oxygen concentration.

As Table 3 explains, sulfur acid concentration is $6.3 \mathrm{mg} / \mathrm{l}$ in an initial solution; it increases by $66 \%$ (i.e. up to $10.45 \mathrm{mg} / \mathrm{l})$ right after the solution was oxygenized with the help of Venturi pipe. Over time, original oxygen concentration decreases gradually and after 65 minutes it decreases down to $9.5 \%$. In this context, ORP value increases from 332 up to $339 \mathrm{mV}$. Maximum ORP value (i.e. $343 \mathrm{mV}$ ) was achieved after 128 minutes of a solution oxygenation. Then, the value remained at $340 \mathrm{mV}$ level. 
Figure 4 shows dependencies of changes in a solution oxygenation as well as in ORP value upon time resulting from processing of data represented in Table 3.

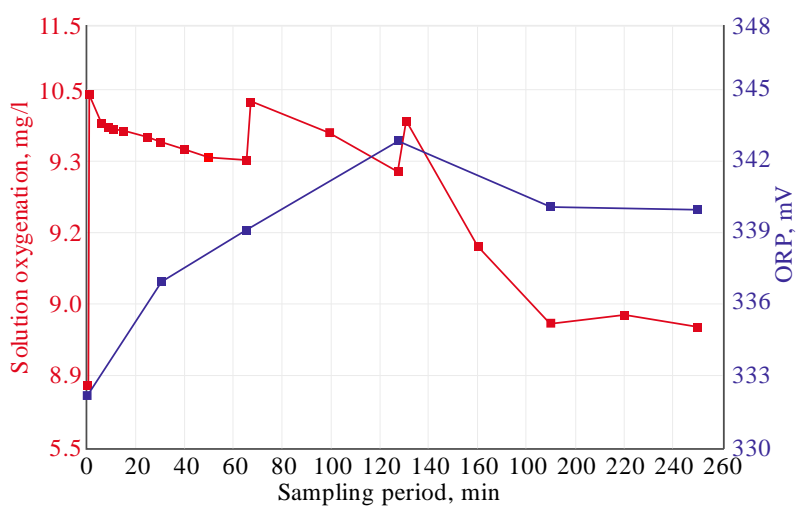

Figure 4. Changes in a solution oxygenation as well as in ORP value depending upon time

As Figure 4 explains, maximum OPR value cannot be observed right after oxygen concentration increase in the solution. The process takes some time. For instance, under the lab conditions, maximum increase was achieved after 120 minutes.

\section{Conclusions}

The research has identified that use of Venturi pipe helps oxygenize a leach solution. In this context, maximum oxygen concentration in the solution is achieved in terms of optimum flow velocity for different pipeline diameters.

Oxygenation degree of a solution depends upon a flow velocity as well as upon a volume of the delivered leaching solution. Moreover, each pipeline diameter has optimum velocity and the delivered solution volume providing its maximum oxygenizing degree. The oxygenizing solution degree depends upon sulfuric acid concentration. The degree experiences its increase along with concentration degree of a sulfuric acid.

Increase in transportation distance of a leaching solution from saturation place results in minor decrease of oxygen concentration in the solution. Increase of oxygen concentration in a leach solution results in the increased OPR of the solution.

To compare with a compressor station, the proposed technique to oxygenize a leach solution using Venturi pipe involves no extra material and labour inputs. When Venturi pipe is equipped with a back valve then a leach solution discharge is avoided if a leaching process stops.

The research, concerning a leach solution oxygenation, has been carried out since it is necessary to intensify metal leaching in ore. Theoretically, oxygen-ferrous iron interaction transits the latter into a ferric form. In addition, if any reagent is available in a solution then it becomes more aggressive which can be used to obtain higher metal content in a pregnant solution.

\section{Acknowledgements}

The studies have been carried out as a part of "Mining process intensification using oxidizers while leaching at Tsentralny site of Mynkunduk deposit" research. The authors express gratitude to Kh.A. Yusupov, Doctor of Engineering, Corresponding member of the NAS of RoK, and S.S. Myrzakhmetov, PhD in Engineering, for their facilitation and valuable help in the process of the studies.

\section{References}

[1] Nikulin, A.A. (2013). Perspektivy mirovogo rynka urana v kontekste novykh tendentsiy razvitiya yadernoy energetiki. Problemy Natsional'noy Strategii, (2), 104-122.

[2] Ali, A., Audi, M., \& Roussel, Y. (2021). Natural resources depletion, renewable energy consumption and environmental degradation: a comparative analysis of developed and developing world. International Journal of Energy Economics and Policy, 11(3), 251-260. https://doi.org/10.32479/ijeep. 11008

[3] Riekhof, M.-C., Regnier, E., \& Quaas, M.F. (2019). Economic growth, international trade, and the depletion or conservation of renewable natural resources. Journal of Environmental Economics and Management, (97), 116-133. https://doi.org/10.1016/j.jeem.2018.04.008

[4] Becken, S. (2014). Oil depletion or a market problem? A framing analysis of peak oil in The Economist news magazine. Energy Research \& Social Science, (2), 125-134. https://doi.org/10.1016/j.erss.2014.03.018

[5] Sorrell, S., Speirs, J., Bentley, R., Brandt, A., \& Miller, R. (2010). Global oil depletion: A review of the evidence. Energy Policy, 38(9), 5290-5295. https://doi.org/10.1016/j.enpol.2010.04.046

[6] Yulusov, S., Surkova, T.Y., Amanzholova, L.U., \& Barmenshinova, M.B. (2018). On sorption of the rare-earth elements. Journal of Chemical Technology and Metallurgy, 53(1), 79-82.

[7] Surkova, T.Y., \& Kozlov, V.A. (2018). Application of hydrolytic precipitation for separation of rare-earth and impurity. Journal of Chemical Technology and Metallurgy, 53(1), 27-30.

[8] Gupta, K., Ripberger, J.T., Fox, A.S., Jenkins-Smith, H.C., \& Silva, C.L. (2021). The future of nuclear energy in India: Evidence from a nationwide survey. Energy Policy, (156), 112388. https://doi.org/10.1016/j.enpol.2021.112388

[9] Zhan, L., Bo, Y., Lin, T., \& Fan, Z. (2021). Development and outlook of advanced nuclear energy technology. Energy Strategy Reviews, (34), 100630. https://doi.org/10.1016/j.esr.2021.100630

[10] Nathaniel, S.P., Alam, M.S., Murshed, M., Mahmood, H., \& Ahmad, P. (2021). The roles of nuclear energy, renewable energy, and economic growth in the abatement of carbon dioxide emissions in the G7 countries. Environmental Science and Pollution Research. https://doi.org/10.1007/s11356-021-13728-6

[11] Kuandykov, T., Nauryzbayeva, D., Yelemessov, K, Karmanov, T., Kakimov, U., \& Kolga, A. (2020). Development and justification of a hydro-impulse method for increasing ore permeability in conditions of uranium borehole production. News of the National Academy of Sciences of the Republic of Kazakhstan, Series of Geology and Technical Sciences, 6(444), 126-133. https://doi.org/10.32014/2020.2518170X.139

[12] Mendygaliyev, A., Arshamov, Y., Selezneva, V., Yazikov, E., \& Bekbotayeva, A. (2021). Prospects for application of multi-spectral earth sensing data in forecasting and searching for reser-voirinfiltration uranium deposits. News of the National Academy of Sciences of the Republic of Kazakhstan, Series of Geology and Technical Sciences, 2(446), 90-97. https://doi.org/10.32014/2021.2518-170X.39

[13] Lyashenko, V.I. (2003). Development of scientific foundations of nature- and resource-saving technologies for in-situ exploitation of uranium deposits. Metallurgicheskaya i Gornorudnaya Promyshlennost', (1), 133-139.

[14] Lyashenko, V.I., Franchuk, V.P., \& Kisly, B.P. (2015). Reengineering of technical-and-technological structure of uranium mine. Gornyi Zhurnal, (1). https://doi.org/10.17580/gzh.2015.01.05

[15] Kanevskij, E.A., Filippov, A.P., Yakubovich, I.A., \& Nevskij, O.B. (1961). Vyshchelachivanie pri pnevmaticheskom peremeshivanii al'bititovoy rudy Zheltorechenskogo mestorozhdeniya s primeneniem $v$ kachestve okisliteley pirolyuzita i nitrozy. NII-10. No. 6357.

[16] Derek, M. (2015). Insight: Uranium is in a holding pattern. Commodity Insights Bulletin, 8 p.

[17] Sukhodolov, A.P. (2010). Mirovye zapasy urana: Perspektivy syr'yevogo obespecheniya atomnoy energetiki. Izvestiya Irkutskoy Gosudarstvennoy Ekonomicheskoy Akademii, 4(72), 166-169.

[18] Boytsov, A. (2014). Worldwide ISL uranium mining outlook: Presentation. Proceedings of the International Symposium on Uranium Raw Material for the Nuclear Fuel Cycle: Exploration, Mining, Production, Supply and Demand, Economics and Environmental Issues, 1-23.

[19] Esmaeel, S.M.A. (2020). Sorption of uranium after carbonate leaching by low cost activated carbon-aluminum ferrisilicate composite. International Journal of Environmental Analytical Chemistry, 1-20. https://doi.org/10.1080/03067319.2020.1758685

[20] Lunt, D., Boshoff, P., Boylett, M., \& El-Ansary, Z. (2007). Uranium extraction: the key process drivers. Journal of the Southern African Institute of Mining and Metallurgy, 107(7), 419-426. 
[21] Polinovskiy, K.D. (2012). Kompleksnyy podkhod k izucheniyu problem intensifikacii processa PSV urana. Gornyy InformatsionnoAnaliticheskiy Byulleten', (7), 1-7.

[22] Pastuhov, A.M. (2013). Otchet o nauchno-issledovatel'skoy rabote po teme: "Primenenie iskusstvennykh okisliteley dlya intensifikatsii protsessa podzemnogo vyshchelachivaniya urana". Ekaterinburg, Rossiya, $167 \mathrm{~s}$.

[23] Luskin, A.Z. (1982). Issledovaniya tekhnologii pererabotki rud mestorozhdeniya Semizbay geotekhnologicheskimi sposobami. Moskva, Rossiya: Fondy CNIL CGHK.

[24] Baibatsha, A., Dussembayeva, K., Bekbotayeva, A., \& Abdullayeva, M.T. (2018). Tails of enrichment factories as the technogenic mineral resources. International Multidisciplinary Scientific GeoConference Surveying Geology and Mining Ecology Management, 18(1), 519-526. https://doi.org/10.5593/sgem2018/1.1/S01.066

[25] Kruglov, O., \& Menshov, O. (2017). To the soil magnetic susceptibility application in modern soil science. $16^{\text {th }}$ International Conference on Geoinformatics - Theoretical and Applied Aspects. https://doi.org/10.3997/2214-4609.201701906

[26] Zhautikov, F.B., Isagulov, A.Z., Zhautikov, B.A., Romanov, V.I., \& Babenko, A.A. (2019). Development and implementation of a device for the separation of metal and slag during tundish filling. Metallurgist, 63(7-8), 672-674. https://doi.org/10.1007/s11015-019-00874-z

[27] Baibatsha, A., Dyussembayeva, K., \& Bekbotayeva, A. (2016). Study of tails enrichment factory Zhezkazgan as a technogenic ore deposits. International Multidisciplinary Scientific GeoConference Surveying Geology and Mining Ecology Management, (1), 579-586. https://doi.org/10.5593/SGEM2016/B11/S01.073

[28] Omarbekov, Ye., \& Yussupov, Kh. (2020). Improving the technology of uranium mining under the conditions of high groundwater pressure. Mining of Mineral Deposits, 14(3), 112-118. https://doi.org/10.33271/mining14.03.112

[29] Aben, E., Markenbayev, Zh., Khairullaev, N., Myrzakhmetov, S., \& Aben, Kh. (2019). Study of change in the leaching solution activity after treatment with a cavitator. Mining of Mineral Deposits, 13(4), 114-120. https://doi.org/10.33271/mining13.04.114

[30] Yusupov, Kh.A., \& Dzhakupov, D.A. (2017). Ammonium bifluoride in chemical treatment of boreholes in in-situ uranium leaching. Gornyy Zhurnal, (4), 57-60. https://doi.org/10.17580/gzh.2017.04.11

[31] Reader-Harris, M. (2015). Venturi tube design. Orifice Plates and Venturi Tubes, 77-96. https://doi.org/10.1007/978-3-319-16880-7_3

\section{Дослідження зміни насичення киснем вилуговуючого розчину при свердловинному видобутку уранових руд}

\section{Е. Абен, Б. Токтарули, Н. Хайруллаєв, М. Слузах}

Мета. Підвищення вмісту урану у продуктивному розчині шляхом розробки технології зміни окислювально-відновного потенціалу вилуговуючого розчину з насиченням його киснем і встановлення зміни насичення від концентрації сірчаної кислоти і відстані транспортування розчину.

Методика. Для встановлення насичення вилуговуючого розчину киснем з урахуванням швидкості його подачі, концентрації сірчаної кислоти та збереження насиченості з часом у лабораторних умовах була виготовлена лабораторна установка, що складається з ємності для розчину, насоса, трубки Вентурі, ємності для установки киснеміра та зливної ємності. При проведенні досліджень змінювалися і варіювалися швидкість потоку розчину, об’єм розчину, що подається, концентрація сірчаної кислоти і відстані від місця насичення до пласта. Насиченість кисню вимірювали за допомогою оксиметру марки AZ 8403, величини рН і окислювально-відновного потенціалу (ОВП) - приладом IT-1101.

Результати. Наведено технологіюнасичення вилуговуючого розчину киснем та результати лабораторних досліджень щодо встановлення впливу концентрації сірчаної кислоти і відстані транспортування розчину на концентрацію кисню у розчині. Встановлено, що з використанням трубки Вентурі можна наситити вилуговуючий розчин киснем, при цьому максимальна концентрація кисню у розчині досягається при оптимальній швидкості потоку. Встановлено, що насичення розчину киснем залежить від концентрації сірчаної кислоти і дещо знижується зі збільшенням відстані транспортування розчину.

Наукова новизна. Встановлено нові залежності концентрації кисню у розчині від швидкості потоку та об’єму розчину; концентрації кисню у розчині від відстані від місця насичення і концентрації сірчаної кислоти.

Практична значимість. Насичення вилуговуючого розчину киснем призводить до збільшення окислювально-відновного потенціалу розчину i, відповідно, до підвищення вмісту корисного компонента у продуктивному розчині. Запропонована технологія відрізняється низькими капітальними витратами, легко інтегрується в існуючу систему та екологічно абсолютно безпечна.

Ключові слова: насичення, кисень, свердловина, сірчана кислота, вилуговуючий і продуктивний розчин, швидкість потоку

\section{Исследование изменения насыщения кислородом выщелачивающего раствора при скважинной добыче урановых руд}

\section{Э. Абен, Б. Токтарулы, Н. Хайруллаев, М. Елузах}

Цель. Повышение содержания урана в продуктивном растворе путем разработки технологии изменения окислительновосстановительного потенциала выщелачивающего раствора с насыщением его кислородом и установление изменения насыщения от концентрации серной кислоты и расстояния транспортирования раствора.

Методика. Для установления насыщения выщелачивающего раствора кислородом с учетом скорости его подачи, концентрации серной кислоты и сохранения насыщенности со временем в лабораторных условиях была изготовлена лабораторная установка, состоящая из емкости для раствора, насоса, трубки Вентури, емкости для установки кислородомера и сливной емкости. При проведении исследований изменялись и варьировались скорость потока раствора, объем подаваемого раствора, концентрация серной кислоты и расстояния от места насыщения до пласта. Насыщенность кислорода измеряли с помощью оксиметра марки AZ 8403, величины рН и окислительно-восстановительного потенциала (ОВП) - прибором ИТ-1101.

Результаты. Приведены технология насыщения выщелачивающего раствора кислородом и результаты лабораторных исследований по установлению влияния концентрации серной кислоты и расстояния транспортирования раствора на концентрацию кислорода в растворе. Установлено, что с использованием трубки Вентури можно насытить выщелачивающий раствор кислородом, при этом максимальная концентрация кислорода в растворе достигается при оптимальной скорости потока. Установлено, что насыщение раствора кислородом зависит от концентрации серной кислоты и незначительно снижается с увеличением расстояния транспортирования раствора.

Научная новизна. Установлены новые зависимости концентрации кислорода в растворе от скорости потока и объема раствора; концентрации кислорода в растворе от расстояния от места насыщения и концентрации серной кислоты.

Практическая значимость. Насыщение выщелачивающего раствора кислородом приводит к увеличению окислительновосстановительного потенциала раствора и, соответственно, к повышению содержания полезного компонента в продуктивном растворе. Предлагаемая технология отличается низкими капитальными затратами, легко интегрируется в существующую систему и экологически абсолютно безопасна.

Ключевые слова: насыщение, кислород, скважина, серная кислота, выщелачивающий и продуктивный раствор, скорость потока 